Figge, F. H. J. \& Salomon, K. (1941-2). J. Lab. clin. Med. 27, 1495.

Fouts, P. J., Helmer, O. M. \& Lepkovsky, S. (1939). Proc. Soc. exp. Biol., N.Y., 40, 4.

Fouts, P. J., Helmer, O. M. \& Lepkovsky, S. (1940). Amer. J. med. Sci. 199, 163.

Fouts, P. J., Helmer, O. M., Lepkovsky, S. \& Jukes, T. H. (1938). J. Nutrit. 16, 197.

Fouts, P. J. \& Lepkovsky, S. (1942). Proc. Soc. exp. Biol., N.Y., 50, 221.

György, P. (1938). Proc. Soc. exp. Biol., N.Y., 37, 732.

György, P. \& Eckhardt, R. E. (1940). Biochem. J. 34, 1143.

György, P., Goldblatt, H., Miller, F. R. \& Fulton, R. P. (1937). J. exp. Med. 66, 579.

Handler, P. \& Featherstone, W. P. (1943). J. biol. Chem. $151,395$.

Hogan, A. G. \& Parrott, E. M. (1940). J. biol. Chem. 132, 507.

Langston, W. C., Darby, W. C., Shukers, C. F. \& Day, P. L. (1940). J. exp. Med. 72, 463.

McKibbin, J. M., Madden, R. J., Black, S. \& Elvehjem, C. A. (1939-40). Amer. J. Physiol. 128, 102.
McKibbin, J. M., Scharfer, A. E., Frost, D. V. \& Elvehjem, C. A. (1942). J. biol. Chem. 142, 77.

Nielsen, E. \& Elvehjem, C. A. (1942). J. biol. Chem. 145, 713.

O'Dell, B. L. \& Hogan, A. G. (1943). J. biol. Chem. 149, 323.

Rhoads, C. P. \& Miller, D. K. (1933). J. exp. Med. 58, 585.

Simmons, R. W. \& Norris, E. R. (1941). J. biol. Chem. 140,679 .

Totter, J. R., Shukers, C. F., Kolson, J., Mims, V. \& Day, P. L. (1944). J. biol. Chem. 152, 147.

Unna, K. \& Sampson, W. L. (1940). Proc. Soc. exp. Biol., N.Y., 45, 309.

Wills, L. \& Stewart, A. (1935). Brit. J. exp. Path. 16, 444.

Wilson, H. E., Doan, C. A., Saslaw, S. \& Schwab, J. L. (1942). Proc. Soc. exp. Biol., N.Y., 50, 341.

Wintrobe, M. M., Follis, R. H., Miller, M. H., Stein, H. J., Alcayaga, R., Humphreys, S., Suksta, A. \& Cartwright, G. E. (1943). Johns Hopk. Hosp. Bull. 72, 1.

Wintrobe, M. M., Miller, M. H., Follis, R. H., Stein, H. J., Mushatt, C. \& Humphreys, S. (1942). J. Nutrit. 24, 345.

Wintrobe, M. M., Samter, M. \& Lisco, H. (1939). Johns Hopk. Hosp. Bull. 64, 399.

Woolley, D. W. (1941). J. biol. Chem. 139, 29.

\title{
The Inhibition of Amine Oxidase by Amidines
}

\author{
By H. BLASCHKO AND RUTH DUTHIE, Department of Pharmacology, Oxford
}

\author{
(Received 25 May 1945)
}

The enzymic oxidation of diamines such as putrescine, cadaverine or histamine by extracts from pig's kidney was found to be somewhat inhibited by guanidine (Blaschko, 1938, 1939), and Zeller (1938) added the observation that some guanidine derivatives, including synthalin (decamethylene diguanidine), acted as more powerful inhibitors. The trypanocidal action of synthalin was the startingpoint of Yorke's (1940) work on diamidines. The action of amidine derivatives on the amine oxidases was therefore more fully studied.

- The present paper gives our results with amine oxidase only; the observations on diamine oxidase will be reported separately.

\section{METHODS}

Rabbit liver was used throughout. The tissue was ground with sand and its own weight of distilled water then added. After centrifuging, the supernatant fluid was dialyzed against distilled water overnight and one-tenth volume of $0.2 \mathrm{M}$ sodium phosphate buffer $\mathrm{pH} \mathbf{7 . 4}$ was added. The substrate used was tyramine. The rate of oxidation was followed manometrically. Open manometers and conical flasks fitted with a side-bulb and a centre tube containing $0.3 \mathrm{ml}$.
$\mathrm{N}-\mathrm{KOH}$ were used: the gas phase was oxygen and the temperature $38^{\circ}$.

For each experiment four vessels (I-IV) were used, each containing $0.5 \mathrm{ml}$. extract $+1 \cdot 1 \mathrm{ml}$. $\mathrm{M} / 15$ sodium phosphate $\mathrm{pH} 7 \cdot 5$, made up to a total of $2 \mathrm{ml}$. with water or addition. The additions were: nos. II and IV, $0.2 \mathrm{ml}$. $0.1 \mathrm{M}$-tyramine hydrochloride; nos. III and IV, $0.2 \mathrm{ml}$. inhibitor. The inhibitor concentration varied according to the activity of the compound. Final concentrations above $10^{-3} \mathrm{M}$ were not used. The experiments were carried on for 30 or $45 \mathrm{~min}$. and readings were taken every $15 \mathrm{~min}$. For the calculation of the percentage inhibition the $\mathrm{O}_{2}$ uptake during either the first 15 or $30 \mathrm{~min}$. was taken, whichever was nearer to $100 \mu$ l. in vessel II. In the great majority of the experiments there was no significant difference in the percentage inhibition found at the end of the different periods.

The substances used in these experiments were kindly given to us by Dr A. J. Ewins, F.R.S., and Dr H. King, F.R.S., Boots Pure Drug Co. Ltd., provided those substances previously studied by Dr W. A. Broom (1936). The substances labelled V147, V187 and V335 and 'Marfanil' (p. 349) we obtained through the kindness of Dr J. Walker. Unless stated otherwise the substances were used as hydrochlorides (or dihydrochlorides). Tetramethylene diguanidine (arcaine) sulphate was a commercial sample from Roche Products.Ltd.; for the synthalin B (dodecamethylene diguanidine dihydrochloride) we are indebted to Dr E. M. Lourie. 


\section{EXPERIMENTS}

\section{(1) Monoamidines of the type $\mathrm{CH}_{3} \cdot\left(\mathrm{CH}_{2}\right)_{n} \cdot \mathrm{C}(: \mathrm{NH}) \cdot \mathrm{NH}_{2}$}

Six representatives of this group were examined, four of which were studied by Broom (1936); in these $n$ was $3,4,8$ and 10 respectively. In addition we had from Dr King two substances in which $n$ was 14 and 16. The results are shown in Table 1.

Compared with some of the amidines to be discussed later, the inhibitions observed were not very strong. The percentage inhibition rose with an increase of the length of the carbon chain up to the substance with $10 \mathrm{CH}_{2}$ groups, but fell off rapidly with the longer chains of 14 and 16.

Table 1. Inhibition of amine oxidase by monoamidines of the type $\mathrm{CH}_{3}\left(\mathrm{CH}_{2}\right)_{n} \mathrm{C}(: \mathrm{NH}) \mathrm{NH}_{2}$

$\begin{array}{cccc} & \left.\text { (Inhibitor concentration } 10^{-8} \mathbf{M}\right) & \\ & \text { Inhibition } & & \text { Inhibition } \\ n & (\%) & n & (\%) \\ 3 & 15 & 10 & 61 \\ 4 & 42 & 14 & 8 \\ 8 & \mathbf{5 0 . 5} & 16 & \mathbf{7 \cdot 5}\end{array}$

(2) Diamidines of the type $\mathrm{NH}_{2}(\mathrm{NH}:) \mathrm{C}\left(\mathrm{CH}_{2}\right)_{n} \mathrm{C}(: \mathrm{NH}) \mathrm{NH}_{2}$

In this series the number of compounds at our disposal was greater. The substance with $7 \mathrm{CH}_{2}$ groups, azelamidine, is one of Broom's substances and we obtained from $\mathrm{Dr}$ King the diamidines with $8,9,10,11,12,13,14$, and $16 \mathrm{CH}_{2}$ groups. There were great differences in the inhibitory activity of the members of this series; two different diamidine concentrations had, therefore, to be employed; the short-chain members, which were relatively weak

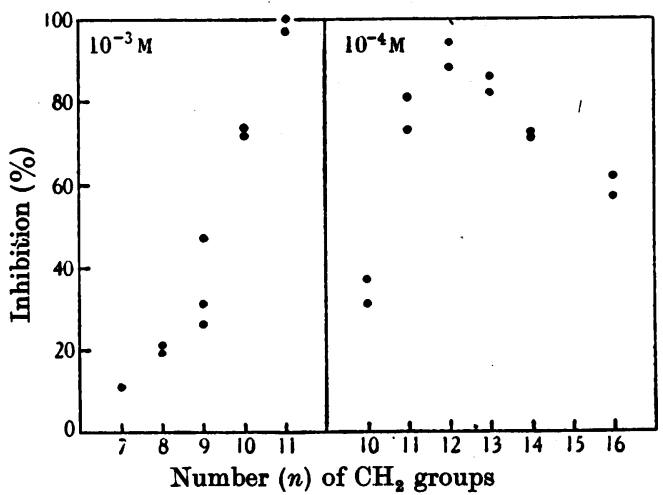

Fig. 1. Inhibition of amine oxidaise by straight-chain diamidines $\mathrm{NH}_{2}(\mathrm{NH}:) \mathrm{C}\left(\mathrm{CH}_{2}\right)_{n} \mathrm{C}$ (:NH) $\mathrm{NH}_{2}$. Inhibitor concentrations as shown. Each dot represents one experiment.

inhibitors, were used in a concentration of $10^{-3} \mathrm{M}$, those with higher mólecular weights in $10^{-4} \mathrm{M}$. The results are shown in Fig. 1. It can be seen that the inhibitor activity rises steadily from $n=7$ to $n=12$ and with increasing chain length falls again.

\section{(3) Diamidines of the type}<smiles>N=C(N)C1CCCC(OCCOC2CCC(C(=N)N)CC2)CC1</smiles>

This group included the two trypanocidal drugs, propamidine $(n=3)$ and pentamidine $(n=5)$. We were given the substances with 1-6 $\mathrm{CH}_{2}$ groups and the compound with $10 \mathrm{CH}_{2}$ ghoups by $\mathrm{Dr}$ Ewins; of these, the substences where $n$ was $3,5,6$ and 10 were the di-isethionates (isethionic acid is 2 hydroxyethane-1-sulphonic acid).

Some of the substances in this group proved to be very powerful inhibitors of the enzyme; Fig. 2

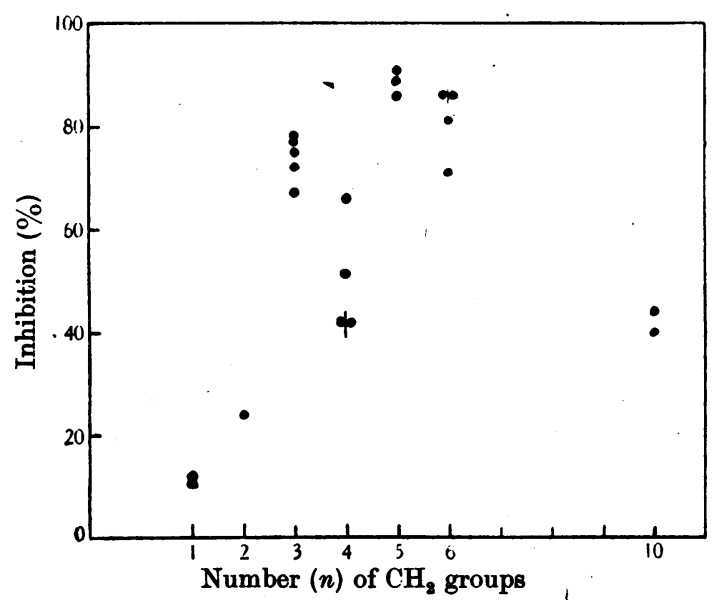

Fig. 2. Inhibition of amine oxidase by diamidines of the type<smiles>N=NC(=N)C1CCCC(OCCOC2CCC(C(=N)N)CC2)CC1</smiles>

Inhibitor concentration $10^{-5} \mathrm{M}$. Each dot represents one experiment.

shows the effect of $10^{-5} \mathrm{M}$ inhibitor. The strongest inhibitors were propamidine and pentamidine, the intermediary substance with $4 \mathrm{CH}_{2}$ groups was less active.

Three methods were employed to decide if the pentamidine inhibition was reversible:

(a) When the extract together with pentamidine was dialyzed for $\mathbf{2 4} \mathrm{hr}$. against water the inhibitory effect of the pentamidine was not removed.

(b) Pentamidine gives a precipitate with salts of dibasic acids, e.g. sodium oxalate and sodium succinate; an experiment was therefore set up in which the inhibition by $10^{-5} \mathrm{M}$-pentamidine was examined in the presence and in the absence of $10^{-2} \mathrm{M}$-sodium oxalate. There was no difference in the percentage inhibition. 
(c) By prolonged centrifugation and repeated washing (three times) with $\mathbf{M} / \mathbf{1 5}$ phosphate buffer a completely insoluble preparation of amine oxidase can be obtained from the rabbit's liver (Bernheim \& Bernheim, 1938). Pentamidine in $10^{-5} \mathrm{M}$ concentration was added to such an enzyme preparation and the suspension was then repeatedly washed with phosphate buffer and centrifuged: after four washings there was no certain evidence that the pentamidine inhibition had been diminished in intensity, but after eight successive washings the inhibition had been noticeably redaced (from 94 to $66 \%$ ). This showed that the inhibition was at least partly reversible, but that the diamidine was very firmly held by the enzyme.

\section{(4) Other amidines}

(a)

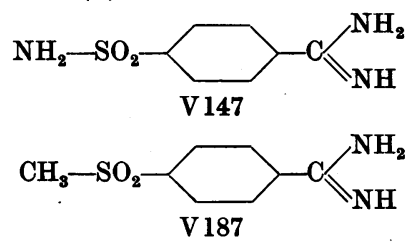

The two substances V 147 and V 187 were tested in $10^{-3} \mathrm{M}$ concentration: the former caused about $57 \%$ inhibition, the latter none. It is interesting that these two amidines had little or no affinity for amine oxidase, although the corresponding amines (Marfanil and V 335),

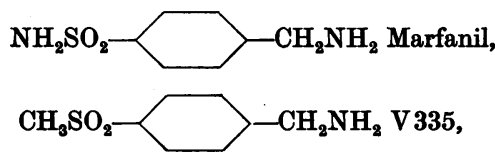

were readily oxidized as was shown by comparison with benzylamine (all substrates $10^{-2} \mathrm{M}$; rabbit liver extract).

\begin{tabular}{cccc}
$\begin{array}{c}\text { Duration } \\
\text { (min.) }\end{array}$ & \multicolumn{2}{c}{$\mathrm{O}_{2}$ uptakes in excess of blank $(\mu \mathrm{l})}$. \\
\cline { 2 - 4 } $\begin{array}{c}\text { With } \\
\text { benzylamine }\end{array}$ & $\begin{array}{c}\text { With } \\
\text { V 335 }\end{array}$ & $\begin{array}{c}\text { With } \\
\text { Marfanil }\end{array}$ \\
30 & 33 & 17 & 6 \\
45 & 47 & 26 & 12 \\
45 & 58 & 32 & 16
\end{tabular}

This experiment confirms a suggestion made by Evans, Fuller \& Walker (1944) that the two amines might be substrates of amine oxidase. The oxidation of Marfanil by guinéa-pig liver has recently been reported by Beyer \& Govier (1945).

(b) Stilbamidine and dimethylstilbamidine

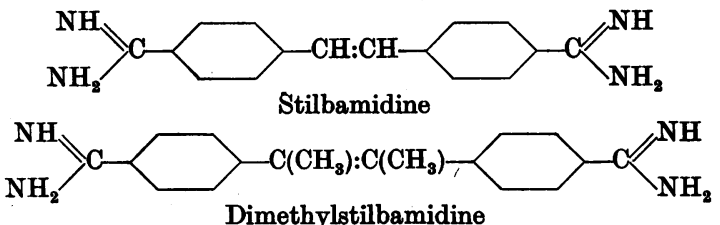

Dimethylstilbamidine
These were tested in $10^{-3} \mathrm{M}$ concentration. The inhibitions in one experiment were $44 \%$ for stilbamidine and $55 \%$ for dimethylstilbamidine. In two more experiments stilbamidine gave inhibitions of 24 and $34 \%$. The stilbamidine was used as the diisethionate, whilst the dimethylstilbamidine was the dihydrochloride.

(c)

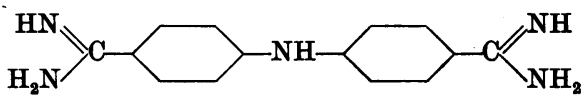

The dihydrochloride $\left(10^{-3} \mathrm{M}\right)$ gave $33 \%$ inhibition.

(d)<smiles>N=C(N)C1CCC(OC2CCC(C(=N)N)CC2)CC1</smiles>

Phenamidine $\left(10^{-3} \mathrm{M}\right)$ inhibited only 15 and $25 \%$ respectively, in two experiments.

\section{(5) Monoguanidines of the type $\mathrm{CH}_{3}\left(\mathrm{CH}_{2}\right)_{n} \mathrm{NHC}(: \mathrm{NH}) \mathrm{NH}_{2}$}

Only the compounds where $n=8$ (the hydriodide) and $n=13$ (the hydrochloride) were tested $\left(10^{-3} \mathrm{M}\right)$. Two additional substances with $n=15$ and $n=17$ were not sufficiently soluble. The inhibitions were $49 \%(n=8)$ and $32 \%(n=13)$.

\section{(6) Diguanidines of the type $\mathrm{NH}_{2} \mathrm{C}(: \mathrm{NH}) \mathrm{NH}\left(\mathrm{CH}_{2}\right)_{n} \mathrm{NHC}(: \mathrm{NH}) \mathrm{NH}_{2}$}

Fig. 3 gives the results for the straight chain diguanidines $\left(10^{-3} \mathrm{M}\right)$. There was a rise of inhibitor activity up to the substance with $14 \mathrm{CH}_{2}$ groups, whilst that with $18 \mathrm{CH}_{2}$ seemed a little less active (at a concentration of $10^{-4} \mathrm{M}$ the figures were $43 \%$ for the substance $n=14$ and $39 \%$ for $n=18$ ).

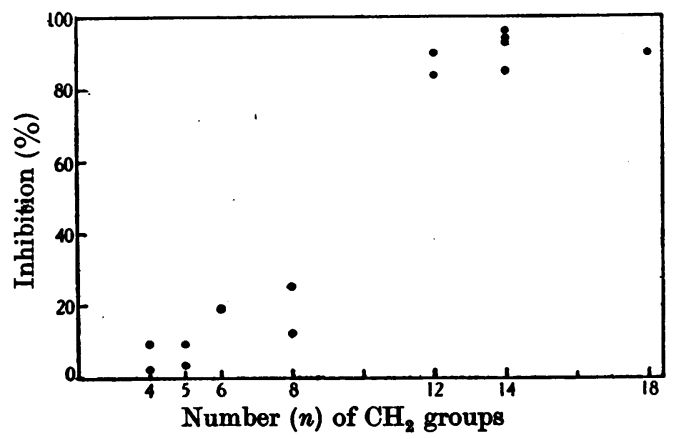

Fig. 3. Inhibition of amine oxidase by diguanidines of the type $\mathrm{NH}_{2} \mathrm{C}(: \mathrm{NH}) \mathrm{NH}\left(\mathrm{CH}_{2}\right)_{n} \mathrm{NHC}(: \mathrm{NH}) \mathrm{NH}_{2}$. Inhibitor concentration $10^{-3} \mathrm{M}$. Each dot represents one experiment.

In addition a spermine derivative,

$$
\begin{array}{r}
\mathrm{NH}_{2} \mathrm{C}(: \mathrm{NH}) \mathrm{NH}\left(\mathrm{CH}_{2}\right)_{3} \mathrm{NH}\left(\mathrm{CH}_{2}\right)_{4} \\
\mathrm{NH}\left(\mathrm{CH}_{2}\right)_{3} \mathrm{NHC}(: \mathrm{NH}) \mathrm{NH}_{2} .4 \mathrm{HCl},
\end{array}
$$

was examined. Its inhibitory activity was relatively low ( $17 \%$ in $10^{-8} \mathrm{M}$ concentration). 
(7) Diisothioureas of the type

$\mathrm{NH}_{2}(\mathrm{NH}:) \mathrm{CS}\left(\mathrm{CH}_{2}\right)_{n} \mathrm{SC}(: \mathrm{NH}) \mathrm{NH}_{2} \cdot \mathrm{HBr}$

The substances, obtained from Dr King, were those with $2,3,6,10$ and $12 \mathrm{CH}_{2}$ groups. The results are shown in Table 2. Of the substances examined the compound with $10 \mathrm{CH}_{2}$ groups was most active.

Table 2. Inhibition of amine oxidase by diisothioureas of the type $\mathrm{NH}_{2}(\mathrm{NH}:) \mathrm{CS}\left(\mathrm{CH}_{2}\right)_{n} \mathrm{SC}(: \mathrm{NH}) \mathrm{NH}_{2}$

\begin{tabular}{rcc}
$n$ & \multicolumn{2}{c}{ İnhibition (\%) } \\
2 & $\overbrace{10^{-3} \mathrm{M}}^{10^{-4} \mathrm{M}}$ \\
3 & 0 & - \\
6 & 0 & - \\
10 & 31 & 87 \\
12 & 100 & 68
\end{tabular}

\section{DISCUSSION}

The experiments described show that amidines have an affinity for amine oxidase, but their affinity, as measured by their inhibitory activity, depends considerably upon the general configuration of the substances examined. This is not surprising. It is known that not all amines react with amine oxidase; here too the molecular configuration determines affinity.

Inhibitors are usually more suitable for the study of the effects of molecular groupings on affinity than are substrates, as the rate of reaction is partly determined by other factors. The results obtained with the monoamidines and diamidines allow the following conclusions:

(1) In each series there is an increase in inhibitory activity with an increasing number of $\mathrm{CH}_{2}$ groups until a certain chain length is reached; beyond this point a further increase in chain length causes a fall in inhibitory activity.

(2) The di-substituted compounds include substances with great inhibitory activity. This may seem surprising, as it is held that diamines have no affinity to amine oxidase. It can be shown, however, that this is not true for all diamines; we have recently found that the straight-chain diamines of the type $\mathrm{NH}_{2}\left(\mathrm{CH}_{2}\right)_{n} \mathrm{NH}_{2}$ with 14,16 and $18 \mathrm{CH}_{2}$ groups respectively are substrates of amine oxidase; there seems to be a maximum of affinity at a certain chain length (Blaschko \& Duthie, unpublished).
The guanidine and isothiourea derivatives owe their inhibitory activity probably also to the presence of the amidine group. Here, too, the di-substituted derivatives are active as inhibitors.

There is no general parallelism of inhibitory action on amine oxidase and trypanocidal effect. For instance stilbamidine, which is highly active as a trypanocidal drug, is not a strong inhibitor. On the other hand, in the series of compounds which includes propamidine and pentamidine, there is a parallelism: the curves of both trypanocidal and inhibitory activities show maxima for the substances with 3 and $5 \mathrm{CH}_{2}$ groups. With the straightchain diamidines we find the maximal inhibitory action in the - $\left(\mathrm{CH}_{2}\right)_{12}-$ compound; King, Lourie \& Yorke (1938) found the maximum trypanocidal activity in the compound with $11 \mathrm{CH}_{2}$ groups.

The demonstration of an inhibitory action of trypanocidal drugs on enzymes is of interest in connexion with possible toxic actions on the host, but it may also have some bearing on the action of these substances on the parasite. Little is known about the mechanism of their therapeutic action, but it seems possible that in the parasite the drugs may interfere with enzymic systems which are in some way chemically related to amine oxidase.

\section{SUMMARY}

1. The inhibitory action of amidine derivatives on the amine oxidase activity of rabbit's liver has been examined.

2. Monoamidines, diamidines, mono- and diguanidines and diisothiourea derivatives inhibit the enzyme.

3. With increasing length of the carbon chain there is at first an increase of activity but with a further lengthening of the chain there is a decrease of inhibitory action.

4. Stilbamidine is not a strong inhibitor of the enzyme, but propamidine and pentamidine inhibit very strongly. The pentamidine inhibition is at least partially reversible.

5. Marfanil and V335 are substrates of amine oxidase, but the corresponding amidines (V147 and V 187) have little affinity for the enzyme.

This work has been carried out while the authors held grants from the Medical Research Council.

\section{REFERENCES}

Bernheim, F. \& Bernheim, M. L. C. (1938): J. biol. Chem. 128, 317.

Beyer, K. H. \& Govier, W. N. (1945). Science, 101, 150.

Blaschko, H. (1938). 16th Internat. Physiol. Kongress

Zurich. Kongressbericht, 3, 73.

Blaschko, H. (1939). J. Physiol. 95, 30 P.
Broom, W. A. (1936). J. Pharmacol. 57, 81.

Evans, D. G., Fuller, A. T. \& Walker, J. (1944). Lancet, 2, 523.

King, H., Lourie, E. M. \& Yorke, W. (1938). Ann. trop. Med. Parasit. 32, 177.

Yorke, W. (1940). Trans. R. Soc. trop. Med. Hyg. 33, 463. Zeller, E. A. (1938). Helv. chim. Acta, 21, 717. 